\title{
VALIDITAS METODE REAL TIME PCR GENEXPERT PADA SUSPEK TB PARU BTA NEGATIF DI RSUD dr. DORIS SYLVANUS
}

\author{
Validity of the Real Time PCR GeneXpert Method \\ for Smear Negative Suspect Pulmonary TB in RSUD dr. Doris Sylvanus
}

\author{
Silvani Permatasari ${ }^{\text {** }}$ \\ Vani Vrenika ${ }^{2}$ \\ Florence Felicia ${ }^{3}$ \\ Malasinta $^{3}$ \\ Ria Eriani ${ }^{3}$ \\ Ni Putu Saraswati ${ }^{3}$ \\ Mery Irayanti ${ }^{3}$ \\ *'Fakultas Kedokteran Universitas \\ Palangka Raya, Kalimantan Tengah, \\ Indonesia \\ 2Mahasiswa DIII Analis Kesehatan, \\ Universitas Muhammadiyah Palangka \\ Raya, Kalimantan Tengah, Indonesia \\ ${ }^{3}$ Departemen Mikrobiologi Klinik \\ RSUD Doris Sylvanus, Palangka Raya, \\ Kalimantan Tengah, Indonesia \\ *email: \\ silvani.permatasari@med.upr.ac.id
}

\begin{abstract}
Abstrak
Tuberkulosis (TB) merupakan penyakit infeksius yang disebabkan oleh bakteri Mycobacterium tuberculosis. Indonesia merupakan salah satu negara berkembang dengan pasien TB tergolong tinggi di dunia. Deteksi yang umum digunakan untuk diagnosis TB adalah dengan pemeriksaan sputum BTA. Hasil BTA negatif tetap memiliki resiko infeksi dan dapat berkembang menjadi aktif. Pemeriksaan molekuler GeneXpert merupakan diagnosis TB yang cepat dengan metode real time PCR. Tujuan penelitian ini adalah melakukan penilaian validitas GeneXpert pada pasien suspek TB paru dengan BTA negatif dibandingkan dengan kultur Loweinstein Jensen. Desain penelitian uji diagnostik ini adalah cross sectional study. Penelitian dilakukan terhadap 40 orang pasien suspek TB paru dengan BTA negatif di RSUD dr Doris Sylvanus. Dilakukan pemeriksaan sputum dengan GeneXpert dan dibandingkan dengan kultur Loweinstein Jensen. Hasil validitas GeneXpert untuk mendiagnosis suspek TB paru dengan BTA negatif yaitu nilai sensitivitas $81,8 \%$, spesifisitas $96.5 \%$, nilai prediksi positif $90 \%$, nilai prediksi negatif $93,3 \%$ dan akurasi $92,5 \%$. Disimpulkan GeneXpert memiliki validitas yaitu sensitivitas, spesifisitas, nilai prediksi positif, nilai prediksi negatif dan akurasi yang tinggi sebagai alat diagnostik pada suspek TB paru BTA negatif.
\end{abstract}

\begin{abstract}
Tuberculosis (TB) is an infectious disease caused by Mycobacterium tuberculosis. Indonesia is one of the developing countries with high TB patients in the world. The most common detection used for TB diagnosis is sputum smear examination. Smear negative pulmonary TB still have a risk of infection and can develop into active. The GeneXpert molecular examination is a rapid diagnosis of TB by the real time PCR method. The purpose of this study was to assess the validity of GeneXpert in smear negative pulmonary TB compared to Loweinstein Jensen's culture. The design of this diagnostic test study is a cross sectional study. The study was conducted on 40 people with smear negative pulmonary TB suspect patients in Dr. Doris Sylvanus Regional Hospital. Sputum examination was performed with GeneXpert and compared with Loweinstein Jensen culture. The results of GeneXpert validity for diagnosing smear negative pulmonary TB suspect are sensitivity $81.8 \%$, specificity $96.5 \%$, positive predictive value $90 \%$, negative predictive value $93.3 \%$ and accuracy $92.5 \%$. It was concluded that GeneXpert has validity that is sensitivity, specificity, positive predictive value, negative predictive value and high accuracy as a diagnostic tool in smear negative pulmonary TB suspect.
\end{abstract}

(C) yearThe Authors. Published by Institute for Research and Community Services Universitas Muhammadiyah Palangkaraya. This is Open Access article under the CC-BY-SA License (http://creativecommons.org/licenses/bysa/4.0/). DOI: https://doi.org//0.33084/jsm.vxix.xxx.

\section{PENDAHULUAN}

Tuberkulosis (TB) merupakan penyakit infeksius yang disebabkan oleh bakteri Mycobacterium tuberculosis. TB masih menjadi masalah kesehatan di dunia yang utama karena merupakan ancaman berbahaya karena dapat menyebabkan kematian. Lebih dari satu pertiga 
Silvani Permatasari, Vani Vrenika, Florence Felicia, Malasinta, Ria Eriani, Ni Putu Saraswati, Mery Irayanti. 202I. Validity of the Real Time PCR GeneXpert Method for Smear Negative Suspect Pulmonary TB in RSUD dr. Doris Sylvanus

penduduk dunia terinfeksi oleh M. tuberculosis. Kasus TB yang tidak diobati meningkatkan kematian.'

Berdasarkan data WHO tahun 2019, Indonesia mengalami peningkatan dalam kasus TB dan menempati ranking 3 dunia setelah India dan China. ${ }^{2}$ Data kasus TB Paru di Provinsi Kalimantan Tengah sebanyak 3518 yang tersebar di 14 kabupaten/kota. Pada tahun 2017 RSUD dr. Doris Sylvanus menjadi rumah sakit dengan temuan TB paru terkonfirmasi bakteriologi dan terdiagnosis klinis mencapai 297 kasus. $^{3}$ Kejadian kasus TB paling tinggi terjadi pada golongan sosial ekonomi lemah yang dipengaruhi oleh status gizi dan kebersihan individu dan kepadatan hunian lingkungan tempat tinggal. Kasus TB yang tinggi di Indonesia mengharuskan perlunya diagnosis dan pengobatan cepat dan tepat sehingga menekan penularan. $^{4}$

Salah satu cara pengendalian tuberculosis (TB) adalah mampu mendiagnosis atau mendeteksi kasus TB secara dini. Beberapa pasien mendapatkan diagnosis TB paru dari keluhan gejala klinis dan kelainan radiologisnya saja. Diagnosis TB yang tepat adalah dengan menemukan bakteri $M$. tuberculosis dalam sputum atau biakan jaringan paru.' Diagnosis TB paru harus ditegakkan melalui pemeriksaan mikroskopis bakteri M. tuberculosis, tes cepat molekuler TB dan kultur biakan. Dari ketiga metode tersebut, pemeriksaan yang banyak digunakan adalah dengan pemeriksaan mikroskopis BTA. Pemeriksaan ini mudah dan terjangkau dari segi biaya, akan tetapi, sputum dengan jumlah sedikit $<5000$ bakteri/ml sulit dideteksi. Sementara, jumlah minim bakteri $M$. tuberculosis sudah dapat menginfeksi orang. ${ }^{4}$

Teknik kultur masih merupakan gold standar karena identifikasi dan sensitivitas yang lebih baik dibandingkan pemeriksaan mikroskopis BTA, Namun, kultur membutuhkan waktu yang lebih lama untuk pertumbuhan bakteri $M$. tuberculosis dengan infrastruktur yang tepat atau di laboratorium tertentu dan tenaga ahli yang profesional, sehingga menjadi hambatan besar untuk perlunya diagnosis dan pengobatan yang cepat bagi pasien. 5,6 Berbagai metode baru telah dikembangkan untuk diagnosis cepat TB dan saat ini teknik diagnostik molekuler merupakan teknik terbaik karena memiliki sensitivitas yang cukup tinggi untuk mendeteksi sampel dengan dengan jumlah bakteri rendah. ${ }^{7,8}$

Tes cepat molekuler TB dapat dengan cepat dan akurat untuk mendeteksi bakteri $M$. tuberculosis adalah dengan pemeriksaan GeneXpert. GeneXpert MTB/RIF adalah suatu alat diagnostik molekuler untuk mendeteksi kasus TB dan resistensi rifampisin. Metode pemeriksaaan GeneXpert menggunakan Real Time Polymerase Chain Reaction Assay (RT-PCR) semi kuantitatif dengan menggunakan tiga spesifik primer dan lima probe untuk mendeteksi mutasi daerah gen rpoB pada $M$. tuberculosis yang berkaitan erat dengan target obat rifampisin. Pengujian dilakukan secara terintegrasi dan otomatis mulai dari isolasi DNA hingga multiplikasinya dalam catridge sekali pakai, hal ini dapat menghindari dari kontaminasi ${ }^{9,10}$ Penelitian invitro menunjukkan batas deteksi bakteri TB dengan metode RT-PCR GeneXpert minimal I3। bakteri/ml sputum dan konsentrasi sputum yang dibutuhkan hanya I $\mathrm{ml}^{\mathrm{II}, 12}$

Program pemerintah stop TB salah satunya adalah diagnosis cepat dan tepat dengan memberikan bantuan alat diagnostik RT-PCR GeneXpert ke seluruh RS pemerintah di Indonesia, salah satunya adalah RSUD dr. Doris Sylvanus di Palangka Raya. Pengujian dengan pemeriksaan mikroskopik BTA juga tetap dijalankan dan terdapat beberapa laporan pasien suspek TB dengan pemeriksaan mikroskopis BTA negatif di RSUD dr. Doris Sylvanus. Menurut WHO (20II), dari 1730 penderita suspek TB atau multi drug resistant (MDR) TB didapatkan 72,5\% menggunakan BTA negatif dan meningkat menjadi 90,2\% menggunakan metode RTPCR Genexpert dengan spesifisitas $99 \%$. $^{13}$ Oleh sebab itu, perlu dilakukan penelitian pemeriksaan dengan metode RT-PCR GeneXpert pada kasus suspek TB 
paru dengan BTA sputum negatif. Hal ini bertujuan untuk mengetahui validitas metode RT-PCR GeneXpert sebagai alat diagnostik yang cepat pada suspek TB pemeriksaan BTA negatif di RSUD dr. Doris Sylvanus.

\section{METODE PENELITIAN}

Penelitian ini merupakan uji diagnostik dengan desain cross sectional study dan dilakukan setelah mendapatkan rekomendasi dari Komite Etik Fakultas Kedokteran UPR. Penelitian ini dilaksanakan pada Oktober 2019 - Februari 2020 di RSUD Doris Sylvanus Palangka Raya. Populasi adalah pasien suspek TB paru dengan BTA negatif di RSUD Doris Sylvanus Palangka Raya. Sampel adalah penderita yang memenuhi kriteria inklusi dan eksklusi. Pada subyek yang potensial dilakukan skrining awal, diterangkan tentang protokol penelitian dan pasien dimintai persetujuan untuk mengikuti penelitian. Besar sampel ditentukan menggunakan rumus:

$$
\mathrm{n}=\frac{(Z \alpha)^{2} \operatorname{Sen}(1-\operatorname{Sen})}{d^{2} P}
$$

Keterangan :

$\mathrm{n}$ :besar sampel

d :presisi penelitian

Za :tingkat kemaknaan

P :proporsi

Sen :sensitivitas uji

Tingkat kemaknaan sebesar 95\%, sensitivitas uji $90 \%$, presisi penelitian sebesar 15\% dengan proporsi pada populasi menggunakan $P=0,4$ sehingga berdasarkan rumus diperlukan jumlah sampel 38,4l6 dan dibulatkan menjadi 40 orang. Kriteria inklusi yaitu pasien suspek tuberkulosis paru dengan BTA negatif, usia lebih dari I 3 tahun, sedangkan kriteria eksklusi yaitu pasien yang menolak mengikuti penelitian.

Adapun alat dan bahan yang digunakan dalam penelitian ini adalah tabung sputum, GeneXpert MTB/RIF, catridge MTB/RIF, sentrifuge, inkubator, cawan petri, Laminar Air Flow dan sputum pasien.
Semua penderita suspek tuberkulosis paru dilakukan pemeriksaan BTA sputum sebanyak 2 kali dengan teknik SPS. Pasien yang hasil pemeriksaan BTA negatif 2 kali dilakukan pemeriksaan rontgen torak. Pasien yang rontgen torak sesuai gambaran TB menurut dokter ahli radiologi dijadikan sampel penelitian. Identitas pasien dicatat yang meliputi nama, umur, jenis kelamin, alamat, anamnesis, lama keluhan, dan pemeriksaan fisik.

Spesimen sputum diambil kembali pada pasien suspek TB paru secara spontan pada pagi hari. Spesimen sputum yang sudah dikumpulkan dan dimasukkan ke dalam botol dilakukan sentrifugasi. Dari deposit hasil sentrifugasi, sputum diinokulasikan untuk penanaman pada media Loweinstein Jensen lalu diinkubasi pada suhu $37{ }^{\circ} \mathrm{C}$. Hasil penanaman di media Lowenstein Jensen dapat diperoleh setelah 6-8 minggu yang dilakukan di Balai Besar Laboratorium Kesehatan (BBLK) Surabaya. Kemudian sputum pasien yang sama diperiksa juga dengan metode RT-PCR GeneXpert. Sputum diinkubasi selama 15 menit di suhu kamar. Selanjutnya sputum diambil dengan pipet khusus dan dimasukkan ke dalam cartridge. Setelah itu cartridge dimasukkan ke dalam alat GeneXpert. Sputum diproses dan diperiksa oleh GeneXpert secara otomatis dan hasil diperoleh \pm 2 jam.

Data yang didapatkan dilakukan analisis statistik deskriptif yang meliputi karakteristik penderita berupa umur, jenis kelamin, dan keterangan pemeriksaan. Kemudian dilakukan penghitungan sensitivitas, spesifisitas, nilai prediksi positif (NPP), nilai prediksi positif (NPP), nilai prediksi negatif (NPN) dan akurasi uji metode RT-PCR GeneXpert dibandingkan uji standar kultur Lowenstein Jensen.

\section{HASIL DAN PEMBAHASAN HASIL}

Telah dilakukan penelitian uji diagnostik pada 40 orang pasien TB paru BTA negatif di Instalasi Rawat Inap Penyakit Dalam RSUD Dr. Doris Sylvanus kota 
Silvani Permatasari, Vani Vrenika, Florence Felicia, Malasinta, Ria Eriani, Ni Putu Saraswati, Mery Irayanti. 202I. Validity of the Real Time PCR GeneXpert Method for Smear Negative Suspect Pulmonary TB in RSUD dr. Doris Sylvanus

Palangka Raya yang memenuhi kriteria inklusi dan eksklusi.

Tabel I. Karakteristik dasar pasien TB paru BTA negatif

\begin{tabular}{ccc}
\hline Variabel (satuan ) & n (\%) & SD \\
\hline Umur (tahun) & & $49(14,8)$ \\
\hline $\mathrm{I} 4-20$ & $\mathrm{I}(2,5)$ & \\
\hline $20-29$ & $4(10)$ & \\
\hline $30-39$ & $6(\mathrm{I} 5)$ & \\
\hline $40-49$ & $\mathrm{I} \mathrm{I}(27,5)$ \\
\hline $50-59$ & $9(22,5)$ \\
\hline$\geq 60$ & $9(22,5)$ \\
\hline Jenis Kelamin & \\
\hline Laki - laki & $30(75)$ \\
\hline Perempuan & $10(25)$ \\
\hline
\end{tabular}

Pada penelitian ini didapatkan umur rerata pasien suspek TB paru dengan BTA negatif adalah 49 (14,8) tahun dengan umur termuda 18 tahun dan umur tertua 76 tahun. Kelompok usia terbanyak adalah usia 40-49 tahun. Pada penelitian ini didapatkan yang berjenis kelamin laki-laki 30 orang (75\%) sedangkan yang berjenis kelamin perempuan 10 orang $(25 \%)$.

Tabel 2. Distribusi frekuensi TB paru BTA negatif berdasarkan hasil kultur

\begin{tabular}{lcc}
\hline $\begin{array}{l}\text { Kultur Loweinstein } \\
\text { Jensen }\end{array}$ & N & $\%$ \\
\hline Kultur positif & $\mathrm{I}$ & 27.5 \\
\hline Kultur negatif & 29 & 72.5 \\
\hline Total & 40 & 100 \\
\hline
\end{tabular}

Pada tabel 2 terlihat hasil kultur Loweinstein Jensen yang positif sebanyak II orang (27,5\%), kultur yang negatif sebanyak 29 orang (72,5\%) dan ada juga hasil metode RT PCR GeneXpert negatif tetapi hasil kulturnya positif sebanyak I orang.

Tabel 3. Distribusi frekuensi TB paru BTA negatif berdasarkan hasil metode RT PCR GeneXpert

\begin{tabular}{ccc}
\hline GeneXpert & N & $\%$ \\
\hline GeneXpert positif & 10 & 25 \\
\hline GeneXpert negatif & 30 & 75 \\
\hline Total & 40 & 100 \\
\hline
\end{tabular}

Pada tabel 3 dibawah ini terlihat hasil pemeriksaan 40 sampel dengan metode RT-PCR GeneXpert, didapatkan yang positif sebanyak 10 orang $(25 \%)$ dan negatif sebanyak 30 orang (75\%).

Pada penelitian ini didapatkan dari 40 pasien TB paru BTA negatif yang diteliti didapatkan pasien positif benar menderita TB paru adalah 9 orang, positif palsu sebanyak 2 orang, negatif palsu I orang dan negatif benar 28 orang. Data disajikan pada tabel 4 .

Tabel 4. Hasil uji diagnostik metode RT-PCR GeneXpert dibandingkan kultur Loweinstein Jensen pada pasien TB Paru BTA negatif

Kultur Loweinstein Jensen GeneXpert Kultur (+) Kultur (-) Total

\begin{tabular}{lccc}
\hline GeneXpert (+) & 9 & I & 10 \\
\hline GeneXpert (-) & 2 & 28 & 30 \\
\hline Total & II & 29 & 40 \\
\hline
\end{tabular}

Dari hasil perhitungan uji diagnostik berdasarkan data tabel 4 didapatkan nilai sensitivitas $81,8 \%$, spesifisitas $96,5 \%$, nilai prediksi positif $90 \%$, nilai prediksi negatif 93,3\%, dan akurasi $92,5 \%$.

\section{PEMBAHASAN}

Penelitian ini dilakukan terhadap 40 orang pasien suspek TB paru BTA negatif di RSUD Dr. Doris Sylvanus kota Palangka Raya dan didapatkan sebagian besar penderita berada pada rentang umur 40-49 tahun yaitu II orang $(27,5 \%)$ dan lebih banyak kasus pada pria (75\%) daripada perempuan yang hanya berjumlah 10 orang (25\%). Peneliti juga tidak menemukan adanya kasus MDR-TB pada 40 pasien. $\mathrm{Hal}$ ini sama dengan penelitian Munoz dkk (20l3) pada 50 pasien dengan TB paru BTA negatif di Barcelona, Hasil yang didapatkan dengan umur rata-rata 49,3 tahun $(20,2 \%)$ terdeteksi lebih banyak jumlah pasien laki-laki yaitu 35 orang (70\%) dibandingkan perempuan 15 orang (30\%). ${ }^{14}$

Di Indonesia laki-laki mempunyai resiko menderita TB I,6 kali lebih besar dibandingkan perempuan. 
Sedangkan dari data RISKESDA 2013 menunjukkan kelompok laki-laki 10\% lebih banyak ditemukan kasus TB daripada perempuan. ${ }^{15}$ Kecenderungan angka penderita TB lebih banyak pada laki-laki usia produktif diduga berhubungan dengan tingkat aktifitas dan pekerjaan serta kurangnya kesadaran untuk menjaga kesehatan agar terhindar dari bakteri TB setiap saat dari penderita lain yang terkena BTA positif maupun yang terkena BTA negatif. Hal ini kemungkinan juga disebabkan oleh faktor lain seperti perbedaan perilaku dimana kebiasaan merokok pada laki-laki (96,3\%) dan perempuan $(3,7 \%) .^{16}$

Pasien suspek TB perlu diketahui mengenai riwayat pengobatan TB sebelumnya. Pentingnya data tentang riwayat pasien tersebut berguna untuk waspada terhadap pemberian obat TB kategori 2 pada pasien tersebut atau terhadap adanya MDR-TB.

Pada penelitian ini didapatkan 2 sampel dengan metode RT-PCR GeneXpert yang MTB negatif, tetapi hasil kultur Loweinstein Jensen adalah MTB positif (false negatif). Kemungkinan hal ini dapat terjadi karena jumlah M. tuberculosis pada sampel berjumlah <|3| bakteri/mL, sehingga pemeriksaan dengan metode RTPCR GeneXpert tidak dapat mendeteksinya. Sedangkan kultur Loweinstein Jensen dapat mendeteksi M. tuberculosis yang jumlahnya 50-100 bakteri/mL sputum. Penyebab lainya adalah karena kultur Loweinstein Jensen selain menumbuhkan $M$. tuberculosis, juga dapat menumbuhkan bakteri Mycobacterium other than tuberculosis (MOTT) sehingga dapat menimbulkan hasil kultur positif. Tamhane A dkk (2009) mendapatkan pertumbuhan bakteri pada kultur sputum MOTT 4 kali lebih banyak dibandingkan pertumbuhan bakteri M.tuberkulosis pada pasien TBHIV dengan BTA negatif yang hasil kulturnya positif. ${ }^{17}$ Nilai hasil metode RT-PCR GeneXpert MTB positif tetapi hasil kultur Loweinstein Jensen MTB negatif (true negatif) menunjukkan satu sampel. Kemungkinan hal ini terjadi karena metode RT-PCR GeneXpert yang mendeteksi DNA bakteri M. tuberculosis yang sudah mati pada sampel sputum sehingga menyebabkan hasil deteksi MTB positif. Kemungkinan pada kultur sputum bakteri tidak tumbuh karena jumlah $M$. tuberculosis yang hidup kurang dari 50-100 bakteri/mL sputum.

Pada penelitian ini didapatkan nilai sensitivitas $81,8 \%$, spesifisitas $96,5 \%$, nilai prediksi positif $90 \%$, dan nilai prediksi negatif 93,3\%. Akurasi pemeriksaan dengan metode RT-PCR GeneXpert dengan kultur Loweinstein Jensen yaitu $92,5 \%$. Hasil yang diperoleh sesuai dengan apa yang diharapkan yaitu alat uji diagnostik yang digunakan untuk menentukan ada atau tidak adanya suatu penyakit memiliki nilai sensitivitas, spesifisitas, dan akurasi yang tinggi sehingga akan lebih memastikan diagnosis pasien.

Pemeriksaan dengan metode RT-PCR GeneXpert ini memiliki nilai sensitivitas yang tinggi, sehingga dapat dipergunakan sebagai alat skrining untuk menjaring pasien yang menderita TB paru, sedangkan nilai spesifisitas yang tinggi dapat menentukan seorang pasien betul-betul menderita TB paru atau sebaliknya tidak menderita TB paru. Metode RT-PCR GeneXpert ini dapat digunakan sebagai alat skrining maupun penentu diagnosis TB paru sehingga pemberian terapi dapat segera diberikan.

\section{KESIMPULAN}

Metode RT-PCR GeneXpert memiliki validitas yaitu nilai sensitivitas, spesifisitas, nilai prediksi positif, nilai prediksi negatif serta akurasi yang tinggi untuk menegakkan diagnosis tuberkulosis paru BTA negatif.

\section{UCAPAN TERIMA KASIH}

Terima kasih untuk RSUD Doris Sylvanus dan FK UPR serta semua pihak yang telah membantu dalam penelitian ini.

\section{REFERENSI}

I. Amin Z, Bahar A. Tuberkulosis paru. Dalam: Buku Ajar Ilmu Penyakit Dalam Jilid I. Edisi ke-6. Jakarta: Interna Publishing 20I4, hlm. 863-72. 
2. World Health Organization. Global Tuberculosis Report 2019, Geneva; 2019.

3. Dinas Kesehatan Provinsi Kalteng, 2014. Profil Dinas Kesehatan Provinsi Kalimantan Tengah, Palangka Raya.

4. Direktorat Jenderal Pengendalian Penyakit dan Penyehatan Lingkungan. 2014. Pedoman nasional pengendalian tuberkulosis. Jakarta: Kementerian Kesehatan.

5. Lyanda A. Rapid TB test. Jurnal Tuberkulosis Indonesia. 2012;8:12-17.

6. Agrawal M, Bajaj A, Bhatia V, Dutt S. Comparative study of GeneXpert with ZN stain and culture in samples of suspected pulmonary tuberculosis. J Clin Diagnostic Res. 2016;10(5): 09-12.

7. Guenaoui K, Harir N, Ouardi A, Zeggai S, Sellam F, Bekri F, et al. Use of GeneXpert Mycobacterium tuberculosis/rifampicin for rapid detection of rifampicin resistant Mycobacterium tuberculosis strains of clinically suspected multi-drug resistance tuberculosis cases. Ann Transl Med. 2016;4(9): 68.

8. Cho SM, Shin S, Kim Y, Song W, Hong SG, Jeong $\mathrm{SH}$, et al. A novel approach for tuberculosis diagnosis using exosomal DNA and droplet digital PCR. Clin Microbiol Infect. https://doi.org/10.1016/j.cmi.2019.11.012

9. Agustina B, Kastasasmita C, Hilmanto D. Comparison of GeneXpert MTB to Mycobacterium tuberculosis culture in children with tuberculosis. Paediatrica Indonesiana. 2019. 59(3): I I3-8.

10. Okonkwo RC, Onwunzo MC, Chukwuka CP, Ele $\mathrm{Pu}$, Anyabolu AE, Onwurah $\mathrm{Ca}$, et al. The Use of the GeneXpert Mycobacterium tuberculosis/ Rifampicin (MTB/Rif) Assay in Detection of MultiDrug Resistant Tuberculosis (MDRTB) in Nnamdi Azikiwe University Teaching Hospital, Nnewi, Nigeria J HIV Retrovirus. 2017. 3(I): I-5.

I I. Dinnes J, Deeks J, Kunst H, Gibson A, Cummins E, Waugh $\mathrm{N}$, et al. A systematic review of rapid diagnostic tests for the detection Health Technol Asses of tuberculosis infection. 2007. I I:I-96

12. Wulandari Y, Wiqoyah N, Mertaniasih NM. 201 I.Nucleic acid amplification of the RPOB region of Mycobacterium tuberculosis in pulmonary tuberculosis diagnosis. Folia Medica Indonesiana. 47(4):224-229.
13. World Health Organization. 20I I. Automated realtime nucleic acid amplification technology for rapid and simultaneous detection of tuberculosis and rifampicin resistance. 20I I: Xpert MTB/RIF System.

14. Muñoz L, Moure R, Porta N, Gonzalez L, Guerra R, Alcaide F. GeneXpert $\AA$ for smear - negative pulmonary tuberculosis: does it play a role in lowburden countries? Diagnostic Microbiology and Infectious Disease. 20I3;75:325-6.

15. Riset Kesehatan Dasar. Badan Penelitian dan pengembangan kesehatan Kementerian RI tahun 2013.

16. Van Rie A, Page-Shipp L, Hanrahan CF, Schnippel K, Dansey H, Bassett J, et al. Point-of-care Xpert ${ }^{\circledR}$ MTB/RIF for smear-negative tuberculosis suspects at a primary care clinic in South Africa. Int J Tuberc Lung Dis 2013;17(3):368-72.

17. Tamhane A, Cheng P, Dobbs T, Mak S, Sar B, Kimerling ME. Predictors of smear-negative pulmonary tuberculosis in HIV-infected patients, Battambang, Cambodia. Int J Tuberc Lung Dis 2009;।3(3):347-54. 